\title{
'... conceived by the Holy Spirit and born of the Virgin Mary': The exposition of the Heidelberg Catechism in the light of present-day criticism
}

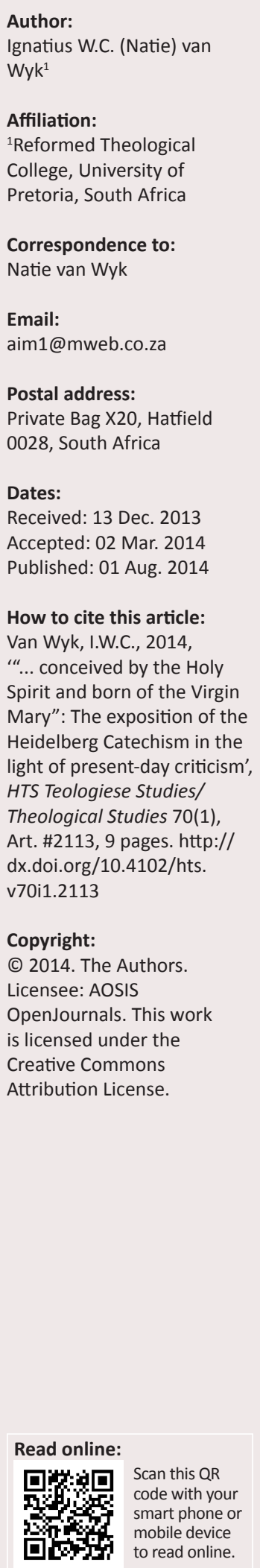

The article is a contribution to the 450 year celebrations of the Heidelberg Catechism (HC). Sunday 14, Questions and Answers 35 and 36 receive attention. It deals with the two statements of the creed '... conceived by the Holy Spirit and born of the Virgin Mary'. The exposition of the HC is compared to the catechisms of Zacharias Ursinus and John Calvin in order to capture something about the historicity of the text. The exposition of the creed is an on-going process. Karl Barth, Eberhard Busch and Jan Milič Lochman are good examples of Reformed theologians who remain faithful to the intention of the $\mathrm{HC}$, but who explain these statements with present-day criticism in mind. The exposition of Peter Berger is valuable because this sceptic argues that the opinion of modern, liberal Protestantism is of no value. The article concludes that the 'virgin birth' as such has no great value. It is only one aspect of the Christian gospel. It also does not proof the divinity of Christ. The divinity of Christ is presupposed.

\section{Introduction}

This article focuses on Questions and Answers 35 and 36 (Sunday 14) of the Heidelberg Catechism (HC) that deals with the two statements '... conceived by the Holy Spirit and born of the Virgin Mary'. The following reasons could be given for this choice: In some Protestant circles, theologians find these statements highly problematic or meaningless (cf. Jenkins [2010] 2011 as one example). Karl Barth's (1964:63) opinion that these words simply deal with the 'great secret of Christmas' is no longer readily accepted. In 1953, Rudolf Bultmann (1965) still wrote with enthusiasm and joy (as a good Lutheran should - cf. Käfer 2011 for Luther's joyful Christmas sermon of 1529) about Christmas as the 'festival of light'. He argued that, in our dark world of evil, created by science and technology, the preaching of the message of the light that came into our world, as well as the faith of the congregation embracing this message, are important beacons of hope to people who do not see light any longer. In 1964, Bultmann (1975) emphasised the importance of the historicity of the Christmas celebrations. The Church's celebration is grounded in an event of the past. This event, however, has changed world history, because this 'eschatological' event has brought the 'new world' into our world. This paradoxical vision of 'historic' and 'eschatological' should be kept alive, should the Church want to remain faithful to the biblical message. Today, one of the leading researchers that disassociates himself from the Christian faith, Gerd Lüdemann (2008:9), rejects the historic reliability of the confession that Jesus was born from the Virgin Mary. He tries to proof from a selection of Early Church documents that the faith of the Church is not based on historical events. He complains (Lüdemann 2008:10-19) about the fact that the church indoctrinates her members via her liturgy and catechesis to believe in and to sing about things that have no historic basis. We do not have enough space to deal with this matter specifically, but it will receive attention within the wider context of the presuppositions of the Christian faith. The emphasis of the article, however, will fall on the intention of the creed as explained by the $\mathrm{HC}$ and theologians standing in this tradition of interpretation. In other words, the article will not primarily deal with historical questions, but with the meaning of these two statements. In the process historical issues will self-evidently receive attention.

At this stage of the history of the Netherdutch Reformed Church of Africa (NRCA), it is important to give attention to the historical development of the text of the HC. At the 70th General Church Assembly in September 2013, some participants indicated that they understand the text of the HC to be a product directly from heaven. They therefore do not know that the text of the HC is the result of months of theological debates at meetings of a committee responsible for drafting the HC. Theological views that could have been considered by the committee as well as formulation proposals will be discussed. Some others, in turn, again made it known that they believe the HC to be merely a product of 16th century Reformed theology, which therefore has only relative historical value. In other words, the insights of the HC cannot be helpful to us today, because its 
authority is limited to one episode in history. The article has the aim to show that the essence of Sunday 14 deals with the faith of the Church of all ages. Sunday 14 has its roots in the Early Church and without these roots, the church of today will stop being church of Jesus Christ.

\section{The Heidelberg Catechism}

\section{The text ${ }^{1}$}

Lord's Day 14:

35 Q. What does it mean that he 'was conceived by the Holy Spirit and born of the virgin Mary'?

A. That the eternal Son of God, who is and remains true and eternal God, took to himself, through the working of the Holy Spirit, from the flesh and blood of the virgin Mary, a truly human nature so that he might also become David's true descendant, like his brothers and sisters in every way except for $\sin$.

36 Q. How does the holy conception and birth of Christ benefit you?

A. He is our mediator and, in God's sight, he covers with his innocence and perfect holiness my sinfulness in which I was conceived.

35 Q. Quid credis cum dicis: Conceptus est per Spiritum Sanctum, natus ex Maria virgine?

A. Quod ipse Filius Dei, qui est, et permanet verus ac aeternus Deus, naturam vere humanam ex carne et sanguine virginis Mariae, operatione Spiritus Sancti assumpsit; ut simul sit verum semen Davidis, fratribus suis per omnia similis, excepto peccato.

36 Q. Quem fructum percipis ex sancta conceptione et nativitate Christi?

A. Quod is noster sit Mediator, est sua innocentia, ac perfecta sanctitate, mea peccata, in quibus conceptus sum, tegat, ne in conspectum Dei veniant.

\section{What does the Heidelberg Catechism say about the pronouncements of the creed?}

Answers 35 and 36 of the $\mathrm{HC}$ are a short summary of the New Testament message about Jesus Christ. It also keeps the Old Testament background of biblical Christology alive. Jesus of Nazareth is said to be the eternal Son of God who became a human being, however without $\sin$. In spite of the fact that he became a human being, just like us, he remained true and eternal God. His incarnation is the work of the Holy Spirit. Mary, who had no sexual intercourse with a man, gave birth, in a human way, to the boy Jesus, who is also God. We benefit from this conception and birth, because we now have a mediator, who in the sight of God, covers our actual and original sin, with his sinless life.

The HC (in accordance with Reformed Christology - cf. Freudenberg 2011:173) interprets the biblical message in line with the classical orthodox decisions of the church on

1.The English translation is taken from the version by the Christian Reformed Church (2011) in North America. The Latin version is taken from the text as presented in the German Reformed Church in the United States of America (GRCUS) (1863) and Heimbucher, Schneider-Harpprecht and Siller (2012).
Christology, namely Nicea and Constantinople (325 and 381) and Chalcedon (451). It did not deviate from the intentions of these decisions, but reformulated it in the light of theological developments that have taken place during the previous centuries (e.g. the debate and decisions on original sin) and the religious questions relevant to that time (e.g. the concept of mediation).

The HC does not say anything about maternity matters, except that Jesus was born from the flesh and blood of Mary. The birth as such receives no special attention. The birth is not seen as proof of his divinity. The statement on the birth, rather, says something about his humanness. The HC starts with the fact that Jesus Christ is God - and he took on a human nature. The phrases 'through the working of the Holy Spirit' and 'the flesh and blood of Mary' are secondary, only helping to explain the main statement. Christ is divine from eternity, and his birth from a virgin does not verify that (cf. Fesko 2013:229-232).

The HC does not explain why God has chosen this way for our redemption. As sinners, we could only be comforted by this mysterious choice (Plasger 2012:70-84). The HC does not speak about wonders and miracles (although it is presupposed). It does not speak about the possibility or impossibility to believe all of this. It just states what Christians believe about Jesus Christ.

\section{Theological opinions that could have influenced the authors of the Heidelberg Catechism}

Little is known about the sources that were used by die committee $^{2}$ that wrote the HC. We can only guess what they probably could have used in this process. If we accept the theory that Zacharias Ursinus was the primary author, one should accept that his teacher and mentor in Wittenberg, Philipp Melanchthon, most probably shaped his theological thinking in many regards (cf. Freudenberg 2011:140-142). Melanchthon's views ([1553] 2010) on this matter would have played an important role in the debates of the committee - and they could therefore be helpful tools in the effort to understand the HC. Melanchthon's German version of his Loci Theologici [Main Themes of the Christian Teaching] of 1553 (only 10 years prior to the publishing date of the $\mathrm{HC}$ ) is one of the important publications that could have been consulted by all the members of the committee - not only because of the German language, but primarily because he dealt with the incarnation in this specific version of his Loci comprehensively.

Ursinus had lengthy discussions with Calvin in Geneva before he came to Heidelberg (cf. Ehmann 2010:94-96, 2012:36-37). One could therefore presume that Calvin's Catechisms (as well as his Institute) also played a guiding

2.I am not repeating the debate on the authorship of the HC. I have dealt with that extensively in a previous article (cf. Van Wyk [2013], footnote 1 and also Bierma ex Gunn [2013]). In short the following: The primary author was Zacharas \& Gunnoe [2013]). In short the following. The primary author was Zacharias Ursinus. Caspar Olevianus also played a big role in the whole process. They were, however, assisted by a large committee comprising other members of the Faculty of Theology at Heidelberg, as well as eminent members of the church leadership Although Ursinus had the main responsibility, the end result was the product of this committee. I will therefore constantly refer to the $\mathrm{HC}$ as a product of teamwork. 
role at the committee meetings. Although the $\mathrm{HC}$ is not a Calvinistic confession as such, the influence of Calvin on the HC, especially through his student Olevianus, is general knowledge. It could therefore be helpful to look at Calvin's explanations of the creed in his catechisms. One can at least get an idea of the theological frame of reference of the committee that wrote the HC (cf. Bierma 2013 for the latest opinion on the sources of the $\mathrm{HC}$ ).

Zacharius Ursinus himself wrote a Small Catechism (Catechesis Minor) in 1561/1562 and a Large Catechism (Catechesis Maior) in 1562/1563 that were used as working documents by the committee (cf. Van Wyk 2011; Bierma 2013:193). A sensible exercise would be to identify phrases or statements that were omitted from the HC. The omissions could clarify the basic intention of the $\mathrm{HC}^{3}$ One should also consider the question whether the final wording of the $\mathrm{HC}$ is the best possible result. Were Ursinus's proposals not maybe the better option?

This exercise is important within the South African context, because many people (at least in the NRCA) believe that our confessional statements or doctrinal standards should be studied as historical documents that did not undergo an historic process of development.

\section{John Calvin}

One presumes that Ursinus and Olevianus knew Calvin's Institute very well. They most certainly made use of his insights in drafting the HC. The probability is high that they considered some of Calvin's formulations and theological statements from his catechisms. By comparing the $\mathrm{HC}$ to Calvin's catechisms, one gets a clearer picture of what the committee eventually decided on.

In his First Catechism of 1538, Calvin (in Hesselink 1997) says that these two phrases emphasise the humanness of the Son of God. His divinity is presupposed and does not need further clarity. He says:

Indeed, he put on our flesh in order that having become Son of Man he might make us sons of God with him ... He was born of the Virgin Mary that he might be recognized as the true son of Abraham and David, who had been promised in the Law and the Prophets; as the true man, like us in all things ... Yet that same one was conceived in the Virgin's womb by the ... power of the Holy Spirit, that he might not be fouled by any physical corruption, but might be born sanctified with the highest purity. (Hesselink 1997:22-23)

In his Catechism of Geneva of 1545 Calvin gave the following answer to the question concerning the meaning of the two sentences (Q 50):

That he was formed in the womb of the virgin, of her substance, to be the true seed of David, as had been foretold by the Prophets,

3.Another obvious exercise would be by looking at his own commentary (Ursinus [1657] 1980:280-294). In this article the concentration, however, falls on the [1657] 1980:280-294).
specific formulations. and that this was affected by the miraculous and secret agency of the Spirit without human connection.

To the question (Q 51), 'Was it of consequence then that he should assume our nature?' he gave the following answer:

Very much so; because it was necessary that the disobedience committed by man against God should be expiated also in human nature. Nor could he in any other way be our Mediator to make reconciliation between God and man.

Calvin also gives a reason why the Holy Spirit had to generate the Son of God (Q 53):

As the seed of man is entirely corrupt, it was necessary that the operation of the Holy Spirit should interfere in the generation of the Son of God, that he might not be affected by this contagion, but endued with the most perfect purity.

\section{Comparing Calvin to the Heidelberg Catechism}

What do we read in the HC that we do not also find in Calvin?:

- 'That the eternal Son of God ... remains true and eternal God.'

\section{Summary}

Calvin did not find a defence against Adoptianism necessary. One could only presume that Calvin was not confronted by this heresy in Geneva in the same way as the people of Heidelberg were.

The following formulations by Calvin were omitted from the $\mathrm{HC}$ :

- 'that having become Son of Man he might make us sons of God with him.'

- 'be recognized as the true son of Abraham and David.'

- 'who had been promised in the Law and the Prophets.'

- 'that this was affected by the miraculous and secret agency of the Spirit without human connection.'

- 'As the seed of man is entirely corrupt ... that he might not be affected by this contagion.'

The authors of the HC were scared of the concept 'Son of Man' (Mk 10:45) and they left out Abraham as Jesus' ancestor. They also left out the promises of the saviour in the Old Testament. Fortunately they did not take up Calvin's idea of the corrupt and contagious seed of man.

\section{Zacharias Ursinus}

The Smaller Catechism: Question and Answer 23:

Why do you say 'conceived by the Holy Spirit and born from the virgin Mary'?

Because I have been taught by God's Word that through the operation of the Holy Spirit the Son of God assumed a human nature from the flesh and blood of the virgin Mary, so that he might at the same time be true God, as he was from eternity, and true son of David, in all things like us his brothers, except for sin, 
and so that by his most perfect obedience he might cover sins in the sight of God. (Bierma 2005:144-145)

The Larger Catechism: Questions and answers 69 and 70:

What do you understand when you say, 'conceived by the Holy Spirit, born of the virgin Mary'? ... That the Son of God, who is the eternal Word of the Father, assumed in the womb of the virgin Mary, without the seed of a man, a soul and human body, formed from the substance of the virgin and perfectly sanctified along with the soul from the very moment of conception by the power of the Holy Spirit - so that according to the promises given to the fathers he might be truly human, like us in all things except for sin, and the true seed of David. ... How do you understand that the Word assumed flesh? ... In this way: that neither was the divine nature changed into the human nor the human into the divine, but that, as soon as the human nature was conceived in the womb of the virgin, these two natures were so united in one person that thereafter they could never be separated, and yet they retain their own distinct properties; and that one and the same Christ is true God and truly human and can do and experience both what is divine and what is human, yet each thing individually according to that nature to which it belongs - just as soul and body are one person. (Bierma 2005:175)

\section{Comparisons between Ursinus's catechisms and the Heidelberg Catechism}

Is HC an improvement?:

- It is not necessarily an improvement in terms of its content, but indeed of its length. The HC is short enough for didactical purposes.

- The use of the term 'mediator' (under the influence of Melanchthon and Calvin - cf. Fesko 2013:232-236) could be problematic to some people, whilst others (such as people confronted by traditional religiosity) may find it illuminating.

- The inclusion of 'original $\sin ^{\prime}$ in answer 36 should be welcomed.

- The important question is whether the phrases that were omitted by the committee did harm to the theological quality of the HC? Which phrases were omitted?:

- From the Small Catechism: '... taught by God's Word' and 'his perfect obedience.'

- The Larger Catechism: 'Son of God who is the eternal Word of the Father', 'without the seed of a man' and 'according to the promises given to the fathers' and lastly the explanation of the definition of Chalcedon.

\section{Summary}

One has to accept that the committee had good arguments why they did not accept the proposals of Ursinus. It should, however, be noted that all the omitted phrases, later, proved to be vitally important. In our church, many people believe that the confessions are second-level sources of theological knowledge that, here and there, have little to do with the Bible (whilst others believe that the formulations of the confession had been taken directly from the Bible). By keeping the phrase 'taught by God's Word' unnecessary confusion could have been avoided.
Karl Barth (cf. below) has constantly emphasised the importance that the man Joseph had nothing to do with this conception (cf. 'without the seed of a man'). However, this phrase was not included in the HC.

In certain scholarly circles it is believed that the Old Testament has almost nothing to do with the birth and life of Jesus Christ. In this regard the words 'according to the promises given to the father' could have had a positive influence.

Lastly, the history of theology has proven that there is a constant need of a new explanation of the definition of Chalcedon. By keeping Ursinus's proposal, the committee could have shown the way to next generations of what should be done every now and then. ${ }^{4}$ I am thus not totally comfortable with the decisions of the committee, in spite of the fact that the end product is a good one.

From this short exercise we learn that the $\mathrm{HC}$ was not revealed to Ursinus and his committee. The $\mathrm{HC}$ is a product of human discourses. The HC is, however, more than just the insights of one generation of theologians. The theological insights of centuries form the cornerstones of the HC. One could therefore state that the $\mathrm{HC}$ is a reliable reflection of the Word of God, although many important aspects of the biblical message were not included in the HC.

\section{Recent interpretations}

Confessional theology or theology bound to the confessions of the church does not merely have the task to repeat the formulations of the fathers. In the light of present-day questions and problems we need to re-interpret the creed as well as the confession's interpretation of the creed. With different words and expressions we need to explain the intention of the creed and the confession in such a way that people today could relate positively to the Christian faith. To help us in this endeavour we lean upon three theologians in the Reformed tradition and one sociologist.

\section{Karl Barth}

In his Credo of 1935, Barth states that this creedal statement boils down to the fact that God became man or that the Word became flesh (see Barth [1935] 1998). This statement, therefore, deals with the Incarnation - as Barth (1964) says:

\footnotetext{
... the mystery ... that Jesus Christ is true God and true man ... the miracle - that Jesus Christ ... has God alone as His Father and therefore the Virgin Mary for His mother. (p. 63)
}

The statement (Barth 1964:64) 'conceived by the Holy Ghost' is a general statement that '... the human existence of Jesus Christ ... has its origin immediately in God, and is therefore

4.Scholars constantly complain about the wording of Chalcedon, but are unsuccessful in providing a better formulation - cf. for instance Kuitert (1992:137-139); Van de Beek ([1998] 1999:72-83, 137-146) and Schröder-Field (2005). According to me, Theißen (2012:238-252) has recently provided an amicable attempt in this regard. Feminist theologians may also rightfully criticise the sexist language of the creed and the definition, but also fail to provide a more acceptable formulation - cf. Praetorius (2011:76-87). 
immediately God's own existence'. The formula 'born of the Virgin Mary' makes the general statement that Jesus Christ '... has also a human-creaturely origin and is therefore also human-creaturely existence'. He therefore concludes:

He was and is God and man; but always both of them, not one without the other ... neither the one nor the other in a merely figurative, provisional, metaphorical sense. Jesus Christ is this: not only man, further, not only an exceptional man, ... no, but as true man so also by origin and in Himself true God. (Barth 1964:64)

Another important remark by Barth (1964:65) is that the incarnation is not '... an objectively completed event'. Faith can never, once and for all, completely understand this mysterious reality. 'Before we believed, it happened ... In faith we follow this event that preceded our faith'.

Barth (1964:66) also reminds us that God alone is the Actor, the Subject in this event. Not God and man; God alone in his free, gracious decision decided that his eternal Son should take on human existence. He alone decided to become God with us, for our sake. This formula says nothing about marriage, and sexuality. It speaks about 'a creation taking place in Mary'. This miracle is a pointer to the 'mystery of God's grace', and this mystery excluded man, sinful man. Barth (1964:71) does not link sinfulness to marriage or sexual life, but defines it as 'the sovereignty of human will and power and activity generally and as such'. The male, arising from the fall and not creation, should therefore be called the bearer of humanity. Because of this, Joseph is excluded as earthly father of Jesus and Mary, the 'woman, becomes the object of revelation' that does not mean 'any apotheosis of woman'.

Barth concludes his exposition by complaining about the fact that theologians tend to assail or undermine this dogma on exegetical grounds. He says:

Properly speaking, decisive assault upon it or doubt of it has come only from failure to understand its character as accompanying sign, and therefore from the idea that it might be rejected as an insufficient hypothesis on which to base the Incarnation, or as a superfluous, miraculous embellishment. But it is neither the one nor the other ... Most certainly ... that it is impossible to separate this content from this form, this form from this content, and that the better course is just to leave this dogma uncriticised. (Barth 1964:72)

Barth ([1947] 1966) discussed these creedal statements again later in his Dogmatik im Grundriss, translated as Dogmatics in outline. This book comprises the lectures Barth had given in Bonn in 1946. Already in the foreword of this book, Barth states that he had said nothing new about these pronouncements. We can therefore only concentrate on aspects that could remove misunderstandings of Barth's position. On the one hand, Barth (1966:96) reminds us that here is not 'only' a sign (or a metaphor) involved, which could be deducted from this mystery. We are not speaking about extraordinary births in general, but about a specific birth. The miracle of Christmas should not be separated from the mystery of the Incarnation. The noetic utterance should be kept alongside the ontic one. The two should not be confused, but the one cannot be without the other. On the other hand, Barth (1966:100) states that the mystery of the Incarnation does not depend on the miracle of Christmas. We cannot postulate that the reality of the Incarnation, the mystery of Christmas, had by absolute necessity to take the form of this miracle. He says:

The true Godhead and the true humanity of Jesus Christ in their unity do not depend on the fact that Christ was conceived by the Holy Spirit and born of the Virgin Mary. All that we can say is that it pleased God to let the mystery be real and become manifest in this shape and form. (Barth 1966:100)

\section{But then again:}

The one thing obviously belongs of necessity to the other. And so we should have to give a warning, too, against parenthesising the miracle of the nativitas and wanting to cling to the mystery as such. One thing may be definitely said, that every time people want to fly from this miracle, a theology is at work, which has ceased to understand and honour the mystery as well, and has rather essayed to conjure away the mystery of the unity of God and man in Jesus Christ, the mystery of God's free grace. (Barth 1966:100)

Barth's (1948) lectures on the Heidelberg Catechism in 1947 do not contribute anything meaningful to what has already been reported above. We can therefore move to one of his scholars.

\section{Eberhard Busch}

Karl Barth's last assistant, Eberhard Busch, explains Sunday 14 of the HC from the perspective of the free God who comes for relationship with us. His exposition is a good example of an explanation of the creed in conversation with present-day thoughts and aspirations. According to Busch (2003:184-200; 2010:167-180), God uses his freedom in order to form a bond with us humans, in order to set up a relationship between himself and us. God chose to co-exist with us, and not to compete with us. He wants to live with us. In his freedom he chose a relationship of coexistence. This is summed up in the message of the angel to Mary '.. and they shall name him Immanuel, which means God with us' (Mt 1:23). God is with us, because he is with us in Christ. By becoming man in Christ, God is with us. God did this in fulfilment of what had already been promised and assured to Israel: 'I will be their God and they will be my people' (Ezk 37:27). Busch (2010) remarks:

Our thinking about God is mistaken if we do not think in this way. We think of an idol if we do not think of God as the God with a human face, the God bound with us humans. (p. 169)

According to Busch, this concept of God is vitally important in the light of modern atheism, or godlessness. To him, godlessness poses a bigger challenge to the church than atheism. He says:

Godlessness ... is not just a theory, but also a particular praxis. In this praxis, humans understand themselves, define themselves, and conduct themselves, as apart from God, separated from God, without God. Godlessness is the theory, and still more the 
praxis, of understanding and dealing with the human realm as the realm only of humans, a realm in which God is not to be found. (Busch 2010:169)

Busch criticises the apologetic approach to godlessness and atheism by the church since the nineteenth century. He is firstly of the opinion that apologetics is not the appropriate way of dealing with this phenomenon. He secondly believes that the church presented the world with the wrong concept of God - a God who remains at a distance and does not identify with humans and their small problems. This false god, this god without a human face, this god who does not want to associate with humans is understandably a god to be ignored. In the light of this, we cannot and should not give up these phrases of the creed and the confessional document (cf. Busch 2010:170-171).

Busch (2010:179-180) also reminds us about another important phrase in Questions and Answers 35-36, namely that Jesus is the eternal Son of God who became man through the blood of Mary and in this way became the descendant of David. The blood that binds Jesus to us is first of all Jewish blood. He as the descendant of David belongs to the people whom God has graciously chosen. God's covenant and oath to Israel have not lost their validity. Rather, God has fulfilled his covenant in Christ and has not made it obsolete. In our church we tend to underplay the importance of the Old Testament in attempts to understand the New Testament. The approach of exegetes to use the so-called 'Mediterranean world' as the background to the gospel of the New Testament has the consequence that the Jewishness of Jesus is underplayed.

Finally, Busch (2010) brings clarity to the question concerning the virgin birth as miracle or wonder. By following the catechism, he re-emphasises that the two phrases concerned deals with the wonder that God became man or that the true God took on true human nature. In terms of miracles, we should not look for something more or something else: The pregnancy and the birth of Christ is the work of the Holy Spirit:

This is underscored in a symbolic way by language about the virginity of Mary. It would be nonsense to understand this language to mean that the child in the manger is the product of a marriage of the Spirit and Mary, still more to say that this establishes the God-humanness of Jesus. In that way what would have come about would be a chimera, and not what actually happens, which is that true God, in and with the one human being, takes on true human nature. That this happens is the wonder of Christmas. Genuine wonders we cannot explain without missing their meaning. We can explain them neither by biological laws nor by other laws of nature, nor by the suspension of these. Genuine wonders we can only point to. The story of the virginity of Mary we can, without qualms, call a legend, which furthermore has little backing in the New Testament. But there are deeply meaningful legends. And this could be one - as a pointer to the fact that it is purely and solely God's work and not wonder that in the One born for us God is with us. As a sign of this, Mary is lifted up here. This is done in such way that the male, who often thinks he can make history because of his potency, here for once can make no history. The virginity of Mary is a pointer to the fact that the incarnation of God in Christ is a divine gift and not a human product. And the preferential treatment of Mary is a pointer to teach us that all humans are what they are only through God's grace, and not through what they make of themselves. (Busch 2010:180)

\section{Jan Milič Lochman}

In 1974-1975 the three lecturers in systematic theology at the University of Basel produced the third volume of their Dogmatics in Dialog. I find the views of the Czech Reformed theologian Jan Milič Lochman illuminating. Lochman (cited in Buri, Lochman \& Ott 1976) defends the view that these pronouncements want to underline the belief that Jesus Christ, being truly God, is definitely also truly human. He finds it necessary to elaborate on the idea that God in Jesus Christ is a human God - a God who wants human beings to become more humane.

Lochman reminds us of the fact that that many discussions did not only take place before the decision of 451 (Chalcedon), but also thereafter. Many voices carry the message that the doctrine of the two natures of Christ was a wrong development (caput mortuum) - especially the interpretation that was given to it by scholastic theologians. He refers to Melanchthon who realised that the scholastic interpretation of the dogma should be rejected. His new approach boiled down to the dictum, 'to know God is to know his benefits' (hoc est Christum cognoscere, beneficia ejus cognoscere). Lochman, following Melanchthon, does not reject the dogma, but rather asks for a new interpretation. He insists, however, that the two-dimensionality of the incarnation should be kept alive. As a good example, he refers to the 1966 statement of the Bohemian Brothers who said: 'We believe that Jesus of Nazareth, in his human existence, is the revelation of the living God'. Lochman also advises that a new interpretation today should concentrate on the universal-historical dimension (universal-geschichtliche Dimension) of biblical Christology. By doing this, emphasis could fall on the 'soteriological-ethical dimensions of the incarnation'. The eyes could be opened to the perspective that the incarnation started the 'humanizing process of the kingdom of God' (das Humanisierungsprozess des Reiches Gottes). This emphasis should remind the world of God's solidarity with the suffering and sufferers. We could avoid the heights of speculation, and come down into the depths of real human history, talking about the human God, the God with us (Lochmann 1976:174-176).

In his exposition of the Apostles' Creed (1982:89), Lochman again made a plea not to undermine the definition of Chalcedon and what goes with it. Western Christianity should realise, by simply looking at the Nicaenum, that the condescension of God (Kondeszendenz Gottes) is a (or the) central theme of the Christian faith. It is unthinkable that one section of the Church could undermine what another section regards as the heart of the matter. Lochman (1982:90-91) complains about the fact that modern Western Christology tends to relativise the divinity of Christ and turn him into 
an example of general human possibilities. Christmas has to do with the presence of God in the history of human suffering. With apologies to Paul, he says, 'if God has not become human in Jesus, then our faith is meaningless'. Lochman (1982:95) knows that modern Protestants find the words natus ex Maria virgine hard to believe. He reminds the readership, however, about a paragraph in Karl Barth's Church Dogmatics (KD I/2:201) that Barth was stunned by the remark of N. Berdjajew, that he could only react with silence, after he had read that Emil Brunner, in his book Der Mittler, admitted that he had difficulties in believing this aspect of the Christian faith.

\section{Peter Berger}

The well-known sociologist and (sceptic) lay theologian, Peter Berger (2004:69), agrees with Barth and his followers that this paradoxical statement reflects a mystery that cannot be grasped by finite human minds; the idea that eternity and time come together in one person, is beyond human comprehension. Interestingly, Berger (2004:79) is also not willing to undermine the consensus of Chalcedon, because this consensus has to do with the 'primacy of soteriology', that is of great importance to him personally.

Berger says that modern people relate with difficulty to the definition of Chalcedon. Most modern theology has gravitated toward 'Antioch' rather than 'Alexandria'. The liberal Protestant interpretation of Jesus could well be labelled 'Ebionite' in tendency. One classic example is John Hick. In 1977 a book was published under his editorship, The myth of God incarnate, which gave rise to a prolonged controversy. The book was a collection of essays by a group of liberal Protestant theologians. The title of the book succinctly sums up their central thesis, as does the title of the essay by Maurice Wiles 'Christianity without incarnation?' (with the disingenuous question mark!). One could summarise the findings of the group by saying that there is no evidence that Jesus, or his immediate disciples, or even Paul, attributed divinity to him: all of this was a later development. To these later developments, modern people are not attracted; however, as Hick (1977:ix) says in the preface, there continues to be the belief of 'honest and thoughtful people who are deeply attracted by the figure of Jesus and by the light which his teaching throws upon the meaning of human life'. Therefore, in order to safeguard this belief, Christian thought must adapt itself to the cognitive presuppositions of the modern mind. As to what this modern mind can supposedly tolerate, Hick wants the 'mythological' elements to be abandoned from the New Testament in order to concentrate on the 'figure of Jesus' and on 'his teaching' so that honest and thoughtful people can go on regarding themselves as, in some sense, Christians. And now, amazingly the comment of Peter Berger (2004):

Here, once more, we have Jesus as an admirable exemplar and as a great teacher. There is no reason to repeat here what I have suggested earlier - that this Jesus is eminently uninteresting and that, 'honestly and thoughtfully', we can do well without him. (p. 77)
Berger is offended by the moralism of liberal Protestantism that operates with a Christology where Jesus never transcends the parameters of this world. He refers to Michael Goulder's contribution (1977) in Hick's book that dreams and therefore says:

I see the growth of a community of self-giving love as the basic thrust of the will of God in human history, and I see that community as exemplified primarily in the church founded by Jesus ... I understand Jesus to have been destined by God to establish the community of selfless love in the world. (Hicks 1977:57, 60)

Berger is more comfortable with the more nuanced voice of Frances Young. She shares the Bultmannian assumptions about the modern mind by saying:

The Christians of the early church lived in a world in which supernatural causation was accepted without question, and divine or spiritual visitants were not unaccepted. Such assumptions, however, have become foreign to our situation. In the Western world ... culture ... has come to be dominated by the human and natural sciences ... to such an extent that supernatural causation or intervention in the affairs of this world has become ... simply incredible. (Young 1977:31)

\section{She ${ }^{5}$, however, also says:}

Salvation and atonement are the core of the Christian message ... Faith demands a doctrine of atonement and atonement means a conviction that God has somehow dealt with evil, with sin, with rebellion; that on the cross, God in Christ entered into the suffering, the evil and the sin of this world - entered the darkness and transformed it into light, into blazing glory. (Young 1977:34-35)

As a sceptic, Berger, however, insists that we, somehow, speak about Christ in terms of the definition of Chalcedon. Jesus is not only a good man; He is also the Son of God. With this mystery we will have to live when we claim to be Christians. In the words of the orthodox theologian, John Macquarrie (1998) he says:

If we say 'God was in Christ', then we are claiming that there was or is something transcendent in Jesus Christ, something that goes beyond a historical human life, something that is eternal ... This is the absolute paradox - that this humble crucified man is also the eternal Word of God. (pp. 99, 114)

Berger, however, does not want to be known as an orthodox Chalcedonian. He therefore reformulates the meaning of these two phrases in the following way:

I can only return to the nexus I proposed earlier in this bookthat God is only credible by way of the kenosis, wherein God is understood as participating in the suffering of this world and as passing through this suffering into triumph. This process is decisively disclosed in Jesus Christ ... If God is really in this process, it cannot be simply as a symbolic representation that Jesus discloses it. In other words, Jesus Christ cannot simply be a metaphor. What is more, the event of God's disclosure in Christ must be cosmic in scope, because it is not just the human condition that is in need of redemption ... For these reasons,

5.For her later contributions along these lines, look at Young ([1991] 2007a:33-48, 2007b:58-80). 
with all reservations, I can give assent to the Christological affirmations in the historic creeds ... and at this point, I find myself in agreement with Bultmann ... [who] suggests that perhaps we should be 'cheerfully content' with saying that Christ is the Word of God. And that Word, the Johannine logos, resounds throughout the cosmos and throughout human history. (Berger 2004:80)

Personally, I find the expositions of Barth, Busch, Lochman and Berger acceptable. To clarify my own position, I also want to introduce a position I do not find acceptable.

\section{Jonathan Bayes}

Jonathan Bayes is a North American Reformed Evangelical. His exposition of the Apostles' Creed may satisfy the type of debates that are conducted in these circles. Members of these churches want to hold on to biblical words and formulations unchanged. When they perhaps find the creeds usable, they also cling to the literal meaning of these formulations; knowing full well that we live in a world dominated by scientific thinking. Their challenge is then to show why, inter alia, the virgin birth is scientifically intelligible. Bayes (2010:64-65) argues that the divine conception and miraculous birth of Christ is scientifically possible and that Christians should not feel embarrassed about their faith. According to him, the Holy Spirit could have created an embryo and then implanted it into Mary's womb. It is common knowledge that the implantation of an embryo produced through fertilisation in vitro into the womb of a woman, whether the biological mother or surrogate, is now medically possible. There is no medical reason why an embryo cannot be implanted in the womb of a woman who is a virgin. The miracle, in which Christians believe, is therefore scientifically possible. This argument is of course not going to help anyone, because a miracle does not depend on scientific proof to be a miracle. The truth of the Bible and the creed do not depend on its scientific verification. You either believe the message behind these words and formulations, or you do not. That science can prove that our faith is not total madness may be an acceptable exercise, but faith does not depend on science to become intelligible.

One should also remember that the emphasis of the creed does not fall on the virgin birth as such. We read that the eternal Son became man from/through/with the help of the flesh and blood of the Virgin Mary. The creed talks about the miracle of the incarnation and not about a miracle of a birth. All emphasis should remain on the Son, and it should not shift to Mary, her pregnancy and her labour.

\section{Conclusion}

The biblical reports on the birth of Jesus are known as 'aetiological legends' (Pannenberg 1972:80). They explain the origins of the resurrected Lord. The wording of the creed about the 'virgin birth of Christ' is a relative matter. On its own it is not important. It is not a measure-stick for true faith. I agree with Lochman (1982:95-99) that this dogma is nothing more than a 'dogma of interpretation' (Deutungsdogma) that 'has the motive of serving the witness about Christ' (ein dienendes Zeugnismotiv). These phrases of the creed only serve the bigger Christological kerygma of the incarnation of the Son of God. It is therefore not a test for orthodoxy or intellectual integrity; these two sentences show the way to the heart of our faith, namely the wonder that God became man. These words serve the bigger theme of Christology and they are not discussion points for a dialogue with biology or genecology. The intention of the creed is a theological one, and is not supposed to stimulate a debate with other sciences. This statement is a theologoumenon that speaks about the mystery that God came into our world, born as a Jewish boy, whose mother had no sexual intercourse with his earthly father or any other man. And here we should leave this matter - for some to accept and for others to reject.

The HC (as a document that is 'accurate in its orthodoxy but relative in its authority' - Ulrichs 2012) has guided many generations on this path. We hope that future generations will also open themselves up to the guidance of the $\mathrm{HC}$ in order to share in the freedom of the Christian faith.

\section{Acknowledgements Competing interests}

The author declares that he has no financial or personal relationship(s) that may have inappropriately influenced him in writing this article.

\section{References}

Barth, K., 1948, Die christliche Lehre nach dem Heidelberger Katechismus, Zollikon, Zürich.

Barth, K., [1935] 1998, Credo: A presentation of the chief problems of dogmatics with reference to the Apostles' Creed, transl. J. McNab, Hodder and Stoughton, London. Barth, K., [1947] 1966, Dogmatics in outline, transl. G.T. Thomson SCM, London.

Bayes, J., 2010, The Apostle's creed: Truth with passion, Wipf \& Stock, Eugene.

Berger, P., 2004, Questions of faith: A sceptical affirmation of Christianity, Blackwell, Oxford.

Bierma, L. (ed.), 2005, An introduction to the Heidelberg Catechism: Sources, history and theology, Baker, Grand Rapids.

Bierma, L., 2013, 'Bronnen van de Heidelbergse Catechismus', in A. Huijgen, J. Fesko \& A. Siller (Hrsg.), Handboek Heidelbergse Catechismus, pp. 193-201, Kok, Utrecht.

Bierma, L. \& Gunnoe, C., 2013, 'Auteurschap van de Heidelbergse Catechismus', in A. Huijgen, J. Fesko \& A. Siller (Hrsg.), Handboek Heidelbergse Catechismus, pp. 73-83, Kok, Utrecht.

Bultmann, R., [1953] 1965, 'Weihnachten', in Glauben und Verstehen: Gesammelte Aufsätze, Dritter Band, Dritte Auflage, pp. 76-80, Mohr, Tübingen.

Bultmann, R., [1964] 1975, 'Was is der Sinn unseres Weihnachtsfestes heute?', in Glauben und Verstehen: Gesammelte Aufsätze, Vierter Band 3., durchgesehene Auflage, pp. 138-140, Mohr, Tübingen.

Buri, F., Lochman, J. \& Ott, H., 1976, Dogmatik im Dialog: Band 3. Schöpfung und Erlösung, Mohn, Gütersloh.

Busch, E., 2003, Credo: Das Apostolische Glaubensbekenntnis, Vandenhoeck, Göttingen.

Busch, E., 2010, Drawn to freedom: Christian faith today in conversation with the Heidelberg Catechism, transl. W. Rader, Eerdmans, Grand Rapids.

Calvin, J., 1545, Catechism of the Church of Geneva, being a form of instruction for children, viewed 10 October 2013, from http://www.reformed.org/documents/ calvin/geneva_catachism/geneva_catachism.html

Christian Reformed Church in North America, 2011, The Heidelberg Catechism, translation approved by the General Synod 2011, Faith Alive Christian Resources, Grand Rapids.

Ehmann, J., 2010, 'Zacharias Ursinus und der Heidelberger Katechismus: Ein Lebensbild', Luther 81(2), 90-103.

Ehmann, J., 2012, 'Von Breslau in die Pfalz - die Wege des Zacharias Ursinus', in $M$. Heimbucher, C. Schneider-Harpprecht \& A. Siller (Hrsg.), Zugänge zum Heidelberger Katechismus: Geschichte, Themen, Unterricht, pp. 33-42, Neukirchener Theologie, Neukirchen-Vluyn. 
Fesko, V., 2013, 'Jezus Christus volgens de Heidelbergse Catechismus', in A. Huijgen, J. Fesko \& A. Siller (Hrsg.), Handboek Heidelbergse Catechismus, pp. 229-237, Kok, Utrecht.

Freudenberg, M., 2011, Reformierte Theologie: Eine Einführung, Neukirchener Theologie, Neukirchen-Vluyn.

German Reformed Church in the United States of America (GRCUS), 1863, Heidelberg Catechism in German, Latin and English with an historical introduction, Tercentenary Edition, Charles Scribner, New York.

Heimbucher, M., Schneider-Harpprecht, C. \& Siller, A., 2012, Zugänge zum Heidelberger Katechismus: Geschichte, Themen, Unterricht. (Ein Handbuch für die Praxis mit Unterrichtsentwürfen auf (CD-Rom), Neukirchener Theologie, Neukirchen-Vluyn.

Hesselink, J., 1997, Calvin's first Catechism: A Commentary, featuring Ford Lewis Battle's translation of the 1538 Catechism, John Knox Press, Louisville. (Columbia Series in Reformed Theology).

Hick, J. (ed.), 1977, The myth of God incarnate, SCM, London.

Huijgen, A., Fesko, J. \& Siller, A. (reds.), 2013, Handboek Heidelbergse Catechismus, Kok, Utrecht.

Jenkins, P., [2010] 2011, Jesus wars: How four patriarchs, three queens, and two emperor decided what Christians would believe for the next 1,500 years, HarperOne, New York.

Käfer, A., 2011, 'Eine Freudenpredigt über Gottes Inkarnation: Martin Luthers Predigt am ersten Weihnachtsfeiertag 1529 über Lk 2,1-11', Luther 82(3), 142-149.

Kuitert, H.M., 1992, Het algemeen betwijfeld christelijk geloof: Een herziening, 12e druk, Ten Have, Baarn

Lochman, J. M., 1982, Das Glaubensbekenntnis: Grundriß der Dogmatik im Anschluß an das Credo, Mohn, Gütersloh.

Lüdemann, G., 2008, Jungfrauengeburt? Die Geschichte von Maria und ihrem Sohn Jesus, zu Klampen Verlag, Springe.

Macquarrie, J., 1998, Christology revisited, Trinity Press International, Harrisburg.

Melanchthon, P., [1553] 2010, Heubtartikel Christlicher Lere, Melanchthons deutsche Fassung seiner Loci Theologici, nach dem Autograph und dem Originaldruck von 1553 herausgegeben von Ralf Jenett und Johannes Schilling. 2. aktualisierte und ergänzte Ausgabe, Evangelische Verlagsanstalt, Leipzig.
Pannenberg. W. 1972, Das Glaubensbekenntnis ausgelegt und verantwortet vor den Fragen der Gegenwart, Siebenstern, Hamburg. (Siebenstern-Taschenbuch 165).

Plasger, G., 2012, Glauben heute mit dem Heidelberger Katechismus, Vandenhoeck, Göttingen.

Praetorius, I., 2011, Ich glaube an Gott und so weiter ... Eine Auslegung des Glaubensbekenntnisses, Gütersloher Verlagshaus, Gütersloh.

Schröder-Field, C., 2005, 'Jesus Christus - wahrhaft Gott und wahrhaft Mensch', in E. Maurer (Hrsg.), Grundlinien der Dogmatik. Festschrift für Gerhard Sauter zum 70. Geburtstag, pp. 161-180, CMZ-Verlag, Rheinbach.

Theißen, G., 2012, Glaubenssätze: Ein kritischer Katechismus, Gütersloher Verlagshaus, Gütersloh.

Ulrichs, H-G., 2012, "AAkkurat orthodox", doch von "relative Autorität", in M. Heimbucher, C. Schneider-Harpprecht \& A. Siller (Hrsg.), Zugänge zum
Heidelberger Katechismus: Geschichte, Themen, Unterricht., pp. 65-76, Heidelberger Katechismus: Geschichte,
Neukirchener Theologie, Neukirchen-Vluyn.

Ursinus, Z., [1657] 1980, Het schatboek der verklaringen over de Heidelbergse Catechismus. Uit de Latijnse lessen. Deel I, opgemaakt door David Pareus, vertaalt door Festus Hommius, hedendaags Nederlands door J. van den Haar, Van den Tol, Dordrecht.

Van de Beek, A., [1998] 1999, Jezus Kurios: De Christologie als hart van de theologie. Spreken over God 1,1. 3e Druk, Kok, Kampen.

Van Wyk, I.W.C., 2013, 'The first commandment in the Heidelberg Catechism: Theological insights of Philipp Melanchthon and Zacharias Ursinus', In die Skriflig / In Luce Verbi 47(2), Art. \#710, 9 pages, http://dx.doi.org/10.4102/ids. Skriflig /In
v47i2.710

Van Wyk, N., 2011, 'The Smaller Catechism of Zacharias Ursinus', Theology and the Church in South Africa 3(2), 83-109.

Young, F., 1977, 'A cloud of witnesses', in J. Hick (ed.), The myth of God incarnate, pp. 13-47, SCM, London.

Young, F., [1991] 2007a, The making of the creeds, 3rd imp., SCM Press, London.

Young, F., 2007b, Brokenness and blessing: Towards a biblical spirituality, Darton, Longman and Todd, London. 